\title{
Reliability and validity of the Polish version of the Movement Imagery Questionnaire-3 (MIQ-3)
}

\author{
Dagmara Budnik-Przybylska $a^{1 \cdot A, B, C, D, E, F, G}$, Marta Szczypinska $a^{2 \cdot A, B, D, E, F}$, Karol Karasiewicz ${ }^{1 \cdot C, D}$ \\ 1: Institute of Psychology, University of Gdansk, Gdansk, Poland \\ 2: University of Gdansk, Gdansk, Poland - postgraduate studies in sport psychology
}

\section{BACKGROUND}

Imagery is often beneficial not only in gaining a psychological advantage when competing but also in building selfesteem and self-confidence. The aim of this study was to examine the reliability and validity of the Polish adaptation of the Movement Imagery Questionnaire-3 (MIQ-3), consisting of 12 questions measuring 3 dimensions: visual internal imagery, visual external imagery and kinesthetic imagery.

\section{PARTICIPANTS AND PROCEDURE}

A sample of athletes $(N=276-102$ women, 174 men $(M=21.25, S D=6.35)$ ) of various disciplines (football, volleyball, karate, swimming, etc.) with different sport experience (from recreation to the national team) filled in the MIQ-3 questionnaire in the Polish language.

\section{RESULTS}

The results of the confirmatory factor analysis (CFA) with maximum likelihood confirmed that the estab- lished three-factor model reflects well the relationships observed in the respondents' answers (satisfactory value of RMSEA below the recommended value of .05 (RMSEA $=.04)$ and a high value of the index above $.90 \mathrm{CFI}$ $(\mathrm{CFI}=.93)$ ). Reliability indicators (composite reliability $\mathrm{CR}$ ) observed for individual factors indicated a very high internal consistency (external visual imagery $=.75$, internal visual imagery $=.79$ and kinesthetic imagery $=.82$ ). The results indicated that good stability and internal consistency were maintained over a 3-week period. In addition, analyses were examined across age, level of experience and gender.

\section{CONCLUSIONS}

The results of the present study support the psychometric properties of the Polish adaptation of the MIQ-3.

KEY WORDS

imagery; athletes; MIQ-3

Corresponding Author - Dagmara Budnik-Przybylska, Ph.D., Institute of Psychology, University of Gdansk,

4 Bażyńskiego Str., 80-952 Gdansk, Poland, e-mail: psydbu@univ.gda.pl

AUthors' CONTRIBUtion - A: Study design - B: Data collection - C: Statistical analysis - D: Data interpretation .

E: Manuscript preparation · F: Literature search · G: Funds collection

to Cite this ARTICLE - Budnik-Przybylska, D., Szczypińska, M., \& Karasiewicz, K. (2016). Reliability and validity

of the Polish version of the Movement Imagery Questionnaire-3 (MIQ-3). Current Issues in Personality Psychology,

4(4), 253-267.

RECEIVED 15.07.2016 · REVIEWED 29.08.2016 · ACCEPTED 17.10.2016 · PUBLISHED 26.10.2016 


\section{BACKGROUND}

Imagery is a cognitive process that may play an important role in the planning and execution of movements or activities. It is often beneficial not only in gaining a psychological advantage during competing but also in building self-esteem and self-confidence. Imagery is a popular and well-established strategy used to improve performance (Morris, Spittle, \& Watt, 2005; Cumming \& Ramsey, 2009). This technique was developed in the 1960s when biofeedback study was particularly fashionable. It is a system of feedback between functions of the body and imagining these functions (Greenwald, 1970).

Imagery is the process of activating sensory (perception) and emotional experience which is used to gather mental resources for future plans and their implementation (Cavallier, 2009).

The use of imagery strategies is varied. Imagery is most commonly used to gain new skills, maintain and strengthen existing skills; as a learning strategy, as a mental warm-up, to solve problems, to manage stress, to build confidence, to regenerate after injury or difficult training, to review past achievements, or to develop psychological skills (Perry \& Morris, 1995). Hall's research confirms that the imagery ability affect the efficiency of use of imagination in sport (Hall, 2001). Rodgers, Hall and Buckolz (1991) believe that athletes who have a better imagery ability use these techniques more often than those athletes who do not have these skills. There are different ways of measuring skills of imagery. One of them is the questionnaire Movement Imagery Questionnaire (MIQ; Hall, Pongrac, \& Buckholz, 1985) and Movement Imagery Questionnaire-Revised (MIQ-R; Hall \& Martin, 1997); the MIQ-RS (Gregg, Hall, \& Butler, 2010) is being developed specifically for use in rehabilitation settings. Another questionnaire is the Vividness of Movement Imagery Questionnaire (VMIQ; Isaac, Marks, \& Russell, 1986) and revised Vividness of Movement Imagery Questionnaire-2 (VMIQ-2; Roberts, Callow, Hardy, Markland, \& Bringer, 2008).

All these questionnaires were designed to assess the imagery ability associated with body movement. Questionnaires designed specifically for sports are the Sport Imagery Questionnaire (SIQ; Martens, 1982), a modified version of the SIQ (Vealey, 1986; Vealey \& Walter, 1993; Vealey \& Greenleaf, 1998), Motivational Imagery Ability Measure for Sport (MIAMS; Gregg \& Hall, 2006), Sports Imagery Ability Questionnaire (SIAQ; Williams \& Cumming, 2011), Sports Imagery Ability Measure (SIAM; Watt, Morris, $\&$ Andersen, 2004) and Imagination in Sport Questionnaire (Budnik-Przybylska, 2014). The latter two are available in the Polish language (Budnik-Przybylska, Karasiewicz, Morris, \& Watt, 2014).
There are studies confirming that there is a difference in brain activation during imaging from an internal and external perspective (Ruby \& Decety, 2001; Fourkas, Avenanti, Urgesi, \& Aglioti, 2006). An external visual imagery perspective is useful during early stages of movement learning and when the corporal shape or coordination is important. It allows the learner to examine the movement from outside of their body (Hardy \& Callow, 1999). Internal visual imagery (seeing with one's own eyes) is more valuable for open skills when timing is important. The individual is able to imagine spatial locations and the time when a movement should be initiated (White \& Hardy, 1995). The kinesthetic dimension is more often used in training and performance of athletes (Smyth \& Waller, 1998; Fery \& Morizot, 2000) and refers to the ability to imagine the feeling of the body during movement (Schmidt \& Wrisberg, 2004). There is research showing that depending on the imagery content and the intended outcome, athletes should use a particular perspective. Some people prefer one perspective more than another, whereas others switch between them (e.g., Cumming \& Ste-Marie, 2001) and change their images by using different viewing angles (Callow \& Roberts, 2010).

Due to the fact that the existing imagery questionnaires in Polish do not measure visual imagery from the external and internal perspective and kinesthetic imagery preceded by real performance of movement, the purpose of the study was adaptation of the MIQ-3 questionnaire. Detailed definitions of those types of imagery (from the visual external and internal perspective and kinesthetic imagery) were presented in the characterization of the MIQ-3 questionnaire.

The MIQ-3 was developed from the Movement Imagery Questionnaire-Revised (MIQ-R; Hall \& Martin, 1997) and is composed of three subscales assessing external visual imagery and internal visual imagery, as well as kinesthetic imagery. Similarly to the MIQ-R, four movements are first physically performed and then imaged three times - once from an external visual perspective, once from an internal visual perspective, and once kinesthetically, resulting in a total of 12 movements physically performed. After that participants rate their imaging from 1 (very hard to see/feel) to 7 (very easy to see/feel), with a higher average score for a subscale representing a greater ease of imaging.

During the introduction participants are provided with definitions of external visual imagery, internal visual imagery and kinesthetic imagery. These are based on imagery literature definitions of external visual imagery, internal visual imagery, and kinesthetic imagery (e.g., Hall, 2001; Callow \& Waters, 2005). External visual imagery is defined as "when you watch yourself performing the movement from an outside point of view or third person perspective. It can be likened to watching yourself on television 
or from another person's perspective." Internal visual imagery is defined as "when you watch yourself performing the movement from an inside point of view or first person perspective. It is as if you were looking out through your own eyes whilst performing the movement and is therefore what you would see while actually doing the movement." Kinesthetic imagery is defined as "the feelings and sensations experienced if you were actually doing the movement. It includes things such as feeling your muscles contract or feeling an object your body makes contact with." (Williams et al., p. 633).

Williams et al. (2012) identified the MIQ-3 to be a valid and reliable questionnaire. The MIQ-3 demonstrated good internal reliability for each subscale, with CR values of .83 (external visual imagery), .79 (internal visual imagery), and .85 (kinesthetic imagery), and AVE values of .55 (external visual imagery), .52 (internal visual imagery), and .59 (kinesthetic imagery). The questionnaire presented a good three-factor model fit to the data $\left(\chi^{2}=75.12, d f=39\right.$, TLI $=.97$, $\mathrm{CFI}=.98, \mathrm{SRMR}=.04, \mathrm{RMSEA}(90 \% \mathrm{CI})=.05(.03-.07))$ along with correlations between each subscale. It indicates external visual imagery, internal visual imagery and kinesthetic imagery ability to be separate but related constructs, which is similar to previous research (e.g., Roberts et al., 2008). The model also demonstrated gender invariance and was a suitable measure of movement imagery ability for both males and females. There were also no significant differences in latent mean scores according to gender, which means that males and females do not differ in movement imagery ability.

Mendes, Marinho and Petrica (2015) in their study on a group of basketball athletes $(N=62$ (31 male and 31 female)) using the MIQ-3 found statistically significant differences between males and females $(p=.010)$ in the kinesthetic subscale $(M=24.35)$ and in the total score $(M=75.19)$, with males achieving a higher average score. They suggested that males have better imagery capacity compared to females and better capacity in the kinesthetic mode.

Nezam, IsaZadeh, Hojjati and Zadeh (2014) found in their research $(N=256$ (145 men and 111 women)), in which the MIQ-3 was used, significant differences among three levels of athletes $(n=81$ elite, $n=85$ sub-elite and $n=90$ non-elite athletes) in internal visual imagery and kinesthetic imagery with a higher level in elite than the sub-elite and non-elite athletes. There were no significant differences among the three groups of athletes in external visual imagery. They concluded that athletes in the highest level use mostly internal visual imagery and kinesthetic imagery.

The main purpose of the current study was to examine the psychometric properties of the Polish language version of the MIQ-3 factor structure of the translated measure, the internal consistency, and test-retest reliability with a sample of Polish athletes. Apart from that, differences in athletes' imagery ability were examined across age and competitive levels and in relation to gender, as an indication of the construct validity of the measure.

\section{PARTICIPANTS AND PROCEDURE}

\section{PARTICIPANTS}

The study included 276 athletes: 102 women and 174 men aged from 12 to 58 years $(M=21.25$, $S D=6.35$ ). They derived from various sports (football, volleyball, karate, swimming, judo, wrestling, etc.). Athletes presented different levels of experience: recreation $(n=113)$, state $(n=135)$, national ( $n=25)$, Olympic team $(n=3)$. Participants were recruited from the University of Physical Education in Warsaw, Gdansk University of Physical Education and Sport, University of Gdansk and the School of Sports Championship in Gdansk.

\section{PROCEDURE}

As mentioned in the introduction, the MIQ-3 questionnaire was used in our study. The first step was the translation of the questionnaire into Polish. The first step of questionnaire adaptation was back and forth translation. A questionnaire was translated by a sworn translator, then by two people familiar with the tool (the authors of the study). After minor adjustments, the final version of the questionnaire in Polish was used in the study.

The study began in January 2016 and lasted a month. Participation in the survey was anonymous and voluntary. Participants first listened to the MIQ-3 questionnaire instructions which researchers were reading. Then they performed the task and assessed their ability to imagine. The survey was preceded by questions about gender, age, discipline, and training experience. The study was conducted in groups. Data collection took approximately 20-30 minutes. Each person agreed to participate in the study. A group of 47 athletes completed the MIQ-3 under the same conditions on two occasions separated by a 3-week interval for the test-retest reliability procedure.

Descriptive, reliability and correlational analyses were conducted using SPSS version 21 . The time stability of the MIQ-3, correlation of the MIQ-3 with age and experience were calculated using Pearson's correlation coefficient. Internal consistency of each of the MIQ-3 subscales was examined using Cronbach's $\alpha$ coefficient. Independent samples $t$-tests were used to examine gender differences in the MIQ-3. 


\section{RESULTS}

\section{CONFIRMATORY FACTOR ANALYSIS}

In order to validate the validity and reliability of the MIQ-3 questionnaire, confirmatory factor analysis (CFA) with maximum likelihood estimation (Arbuckle, 2006) was carried out on a dataset from a random sample of $N=276$ athletes in various disciplines. The analysis was conducted using AMOS 21 for Windows. The model assumes that three questionnaire factors are represented as latent variables reflected in observed answers to questionnaire items. Confirmatory analysis is responsible for verifying whether the established model (structure) actually is reflected in the data, mainly used to assess the goodness of fit of the measurement model. Summary statistics for the estimated model (Ferguson \& Takane, 2009) are represented in Table 1.

Interpreting results of the analysis, it can be said that the established three-factor structure reflects well the dependences observed in the respondents' answers. The satisfactory value of RMSEA below the recommended value of .05 and the high value of the CFI index above .90 indicate that the measured model of imagery ability allows an accurate description of actual skills.

Indicators of reliability (composite reliability) observed for the individual factors confirm a very high internal consistency, which means that individual items are also characterized by high discriminative power. This factor indicates how the test item differentiates a given population in terms of attributes, measured by the whole test.

This is confirmed by results presented in Figure 1, where factor loadings for the questionnaire items exceed the value of .70, when many authors recognize the value of .50 as satisfactory (Konarski, 2010; Kenny, 2004; Howell, 2013).

Table 1

Summary statistics for estimated model

\begin{tabular}{lcccc}
\hline Estimate & CR & AVE & ASV & MSV \\
\hline External & .75 & .57 & .56 & .74 \\
Internal & .79 & .62 & .65 & .74 \\
Kinesthetic & .82 & .68 & HI90 $=.062$ & .57 \\
RMSEA & .04 & LO90 $=.021$ & & \\
CFI & .93 & & & \\
TLI & .87 & & & \\
GFI & .89 & & \\
AGFI & .83 & & \\
RMR & .25 & & \\
$\chi^{2}(d f=51)$ & 76.98 & & \\
\hline
\end{tabular}

At the same time, a high variance of latent factors (AVE) was explained in the model, where the lowest index value AVE significantly exceeds the recommended value of .50 (Howell, 2013; Kenny, 2004). The index value indicates that items accurately reflect the actual result obtained by a participant for the individual scales of the questionnaire.

\section{GENDER INVARIANCE}

In order to estimate sex differences in MIQ-3 structure in the Polish athlete population, several multigroup CFA models were tested. In the first step the unconstrained model was estimated using the maximum likelihood method. In the second step the model with equal factor loadings between both sexes was constrained. In the last step the model assuming equal latent means in imagery subscales for males and females was examined. This procedure is equivalent to Williams et al. (2012). Results are presented in Table 2.

Results of the CFA analysis indicate that the model assuming an independent fit between sexes is not statistically different from the model assuming independent factor structure $\left(\chi^{2}(57)=63.02, p=.272\right)$ or equal latent means in estimated factors $\left(\chi^{2}(54)=\right.$ $73.25, p=.052)$. It means that the factor structure of MIQ-3 is identical in the male and female athlete population and also the intensity of imagery subscales is the same in both sexes.

\section{TEST-RETEST}

A test-retest study was conducted after 3 weeks on a group of 47 people. The results, shown in Table 3, indicate that the MIQ-3 has good stability after 3 weeks. The highest correlation was observed in the external visual imagery $(r=.70)$ and the lowest in the internal visual imagery $(r=.62)$. 


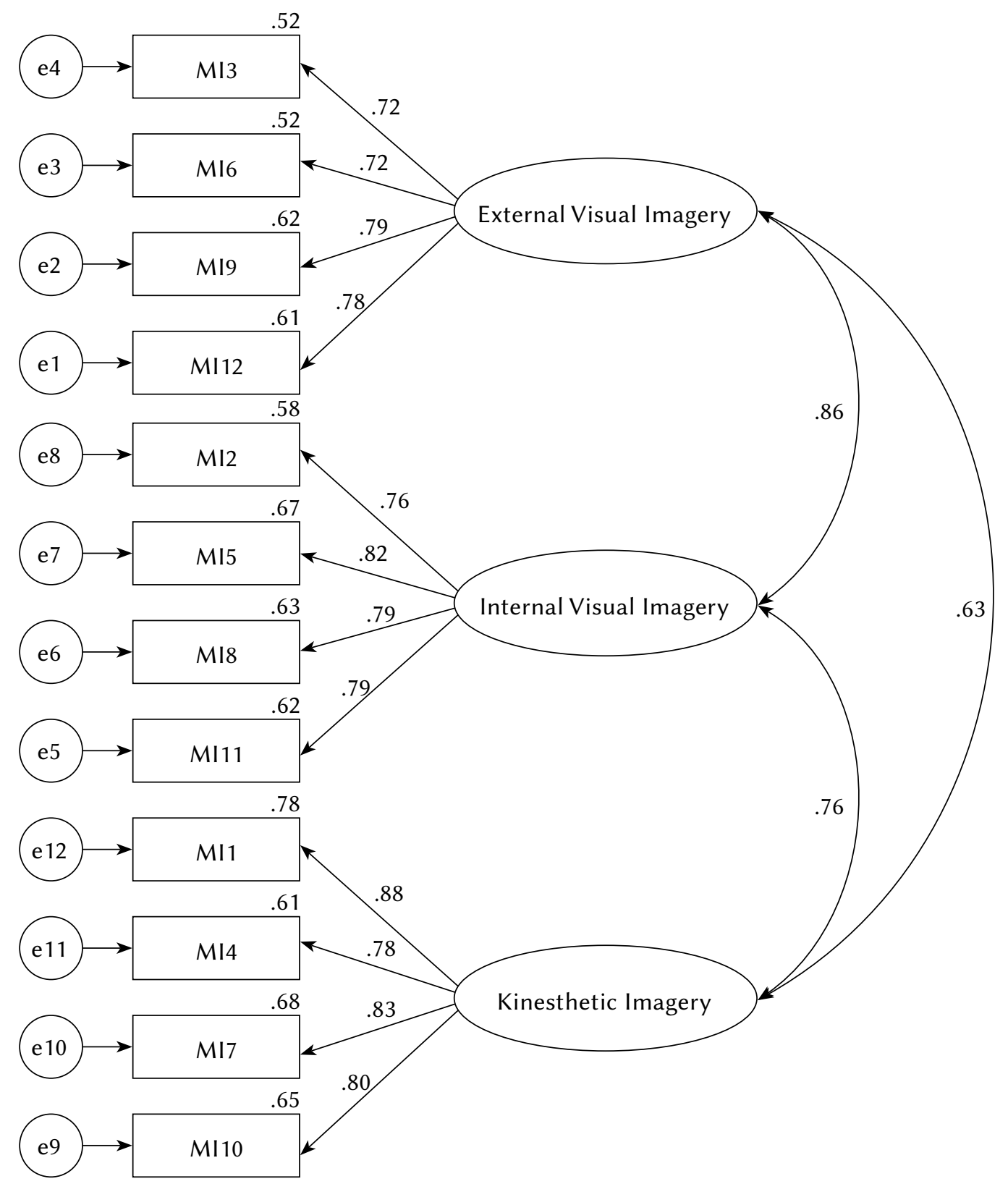

Figure 1. Factor structure of MIQ-3.

\section{MIQ-3 AND AGE AND EXPERIENCE}

Data presented in Table 4 show that there was only one significant correlation $(r=.12, p=.028)$ between internal visual imagery and experience where more experienced athletes achieved higher scores. In other subscales there were no statistically significant correlations among MIQ-3 and age and experience (years of training experience).

Table 2

Summary of analysis of invariance

\begin{tabular}{lcccccccc}
\hline & \multirow{2}{*}{$\chi^{2}$} & $d f$ & $p$ & RMSEA & CFI & \multicolumn{3}{c}{ Change statistics } \\
\cline { 7 - 9 } & & & & & & $\chi^{2}$ & $d f$ & $p$ \\
\hline Unconstrained model & 207.69 & 163 & .010 & .07 & .90 & & & \\
Equal loadings & 144.67 & 106 & .007 & .09 & .90 & 63.02 & 57 & .272 \\
Equal latent means & 134.44 & 109 & .050 & .07 & .91 & 73.25 & 54 & .052 \\
\hline
\end{tabular}


Psychometric characteristics of the MIQ-3

Table 3

Alphas and time stability correlation values for MIQ-3 subscales

\begin{tabular}{lccccc}
\hline & Time stability & Cronbach's $\alpha$ & Cronbach's $\alpha$ & \multirow{2}{*}{$t(47)$} & \multirow{2}{*}{$p$} \\
\cline { 3 - 4 } & & Time 1 & Time 2 & \\
\hline Internal & .62 & .68 & .78 & -.73 & n.s. \\
External & .70 & .72 & .75 & .27 & n.s. \\
Kinesthetic & .65 & .68 & .81 & .20 & n.s. \\
\hline
\end{tabular}

Table 4

Correlations among MIQ-3 and age and experience

\begin{tabular}{lcc}
\hline & Age & Experience \\
\hline External visual imagery & -.07 & -.02 \\
Internal visual imagery & -.05 & $.12^{*}$ \\
Kinesthetic imagery & -.01 & .06 \\
\hline Note. ${ }^{*} p<.05$ & &
\end{tabular}

\section{DISCUSSION}

The aim of this study was to examine the validity and the reliability of the Polish adaptation of the MIQ-3 questionnaire. The first step was translation of the MIQ-3 and confirmation of the correspondence of the Polish version to the original English version. Then, athletes' scores on the MIQ-3 were analyzed to evaluate the confirmatory factor structure, internal consistency of the measure, and test-retest reliability. Relevant demographic characteristics including age, experience and gender were examined for differences as an indication of the construct validity of the MIQ-3.

The results of this study confirm the psychometric properties of the MIQ-3 in the group of Polish athletes. The three-factor structure (as it was in the original version) accurately reflects the relationships observed in the respondents' answers. They were confirmed by high scores of model fit indices. Indicators of reliability observed for the individual factors illustrated a very high internal consistency - factor loadings for the questionnaire items exceed the value of .70. At the same time, a high variance was explained in the model of latent factors (AVE). These results confirmed that the questions differentiated respondents in terms of the measured characteristics. It is also important that the item corresponded to the scale. Furthermore, the Polish version of the MIQ-3 had good stability after 3 weeks. Unusually, the reliability of the scale was better at the second time than in the first trial, where the most common relationship is reversed. It can be explained that the tasks at the first time were difficult for respondents (they could not imagine). The differences, however, were not statistically significant.
Significant demographic characteristics, including age, length of training experience and gender, have been studied as an indicator of construct validity of the MIQ-3. As for the experience of the respondents, there was only one significant correlation $(r=.12$, $p=.028)$ in athletes, which occurred on the scale of internal visual imagery where more experienced athletes achieved higher scores. In other scales there were no other differences between beginners and more experienced respondents, which is not consistent with previous studies concerning imagery in sport (Elfving, Riches, Lintunen, Watt, \& Morris, 2001; Cumming \& Hall, 2002). These results correspond to the research of Nezam et al. (2014) using the MIQ-3 in which elite athletes achieved a higher level in internal visual and kinesthetic imagery. In our study athletes representing recreational and state levels mostly took part. The group of elite athletes was not very large, and this might be the reason why in only one subscale the correlation was discovered. In the study of Cumming and Hall (2002) non-elite athletes considered imagery as being less relevant to their competitive performance and practiced imagery much less than more elite athletes.

With regard to gender the results were in line with previous studies, which indicated gender invariance in the imagery ability (Campos, 2014; Williams et al., 2012; Bhasavanija, Vongjaturapat, Morris, \& Muangnapo, 2011; Hall, 2001; Richardson, 1994, 1999; Abma, Fry, Li, \& Relyea, 2002; Lorant \& Nicholas, 2004; Vadocz, Hall, \& Moritz, 1997). Despite the fact that there was some evidence where males and females presented different imagery generating capabilities, it should be pointed out that different aspects of imagery were examined and only limited differences were discovered (Ozel, Molinaro, \& Larue, 2001; Richardson, 1995; Taktek, 2004; Campos, Pérez-Fabello, \& Gómez-Juncal, 2004; Williams \& Cumming, 2011; Budnik-Przybylska, 2014). For example, females reported higher visual imagery ability than males in some MIQ studies (Atienza, Balaguer, \& Garcia-Merita, 1994; Goss, Hall, \& Buckolz, 1983). In another study, where the MIQ-R was used, the results also indicated that the model fit females better than males (Monsma, Short, Hall, Gregg, \& Sullivan, 2009). Contrary to the above results, Mendes et al. (2015) in their study using MIQ-3 found that males 
had better imagery capacity compared to females and better capacity in the kinesthetic mode. However, that study was conducted in one specific sport discipline, basketball, and the group of respondents was not large ( $n=62$, 31 females and 31 males). Our research confirmed that gender differences do not exist in movement imagery ability, as in the original study (Williams et al., 2012).

There was no significant correlation between age and imaging visual and kinesthetic abilities, which corresponds to previous studies on the general imagery ability (Budnik-Przybylska, 2014; Bhasavanija et al., 2011). In Campos's study (2004) males had better imagery capacity than females at the age between 20 and 40 years. However, so far there have been no studies evaluating the relationship between age and MIQ-3.

Limitations of the research were related to the sample, because the recruitment of participants according to sport type and age was not systematic. Some sports disciplines and age groups were overor under-represented. The same was true of the participants' level. Ruiz and Watt (2014) suggested that studies in the imagery domain associated with the psychometric evaluation should contain similar numbers of athletes recruited to the research regarding sport type, competitive level, task type and function. Our research did not involve establishing concurrent validity of the MIQ.

Future research will concern further validation of the Polish version of the MIQ-3. Data could be collected more systematically using specific ages and groups of athletes, for example, one discipline or team and an individual sport. Additionally, concurrent validity of the MIQ-3 compared with other questionnaires measuring sport imagery ability and use, e.g. KWS (Imagination in Sport Questionnaire; Budnik-Przybylska, 2014) should be established. Nevertheless, our results have provided valuable support for the Polish language version of the MIQ-3.

This questionnaire can be used in scientific research, e.g. with specific ages and groups of athletes, one discipline or team and an individual sport or psychophysiological characteristics of athletes during performing imaging, etc.

This questionnaire may help researchers, coaches, psychologists and athletes to determine whether athletes have a high or low ability of visual internal, external, and kinesthetic imaging, and then develop or modify individual imagery training to support their performance (Sheehan, Ashton, \& White, 1983).

\section{CONCLUSIONS}

The results of the present study support the psychometric properties of the Polish adaptation of the MIQ-3. This questionnaire is suitable for researchers and can be applied by sport psychologists interested in measuring imagery ability and visual internal, visual external and kinesthetic dimensions. In research and applied work the MIQ-3 may be used for various purposes, for example with other Polish language imagery questionnaires as a screening tool for imagery training and a method of assessing the effectiveness of the interventions.

\section{REFERENCES}

Abma, C. L., Fry, M. D., Li, Y., \& Relyea, C. (2002). Differences in imagery content and imagery ability between high and low confident track and field athletes. Journal of Applied Sport Psychology, 14, 67-75.

Arbuckle, J. (2006). AMOS 7: A structural equation modeling program. Chicago: Smallwaters.

Atienza, F., Balaguer, I., \& Garcia-Merita, M. L. (1994). Factor analysis and reliability of the Movement Imagery Questionnaire. Perceptual and Motor Skills, 78, 1323-1328.

Bhasavanija, T., Vongjaturapat, N., Morris, T., \& Muangnapo, P. (2011). Validation of the sport imagery ability measure in Thai for golf. Thai Journal of Sports Sciences, 8, 1-18.

Budnik-Przybylska, D. (2014). The Imagination in Sport Questionnaire - reliability and validity characteristics. Current Issues in Personality Psychology, 2, 68-80.

Budnik-Przybylska, D., Karasiewicz, K., Morris, T., \& Watt, A. (2014). Reliability, factor structure, and construct validity of the Polish version of the sport imagery ability measure. Current Issues in Personality Psychology, 2, 196-207.

Callow, N., \& Roberts, R. (2010). Imagery research: An investigation of three issues. Psychology of Sport and Exercise, 11, 325-329.

Callow, N., \& Waters, A. (2005). The effect of kinesthetic imagery on the sport confidence of flatrace horse jockeys. Psychology of Sport and Exercise, 6, 443-459.

Campos, A. (2014). Gender differences in imagery. Personality and Individual Differences, 59, 107-111.

Campos, A., Pérez-Fabello, M., \& Gómez-Juncal, R. (2004). Gender and age differences in measured and self-perceived imaging capacity. Personality and Individual Differences, 37, 1383-1389.

Cavallier, F. J. P. (2009). Wizualizacja [Visualisation]. Rebis: Poznań.

Cumming, J., \& Hall, C. (2002). Deliberate imagery practice: The development of imagery skills in competitive athletes. Journal of Sports Sciences, 20, 137-145.

Cumming, J., \& Ramsey, R. (2009). Imagery interventions in sport. In S. D. Mellalieu \& S. Hanton (eds.), Advances in applied sport psychology: A review (pp. 5-36). London: Routledge. 
Cumming, J., \& Ste-Marie, D. M. (2001). The cognitive and motivational effects of imagery training: A matter of perspective. The Sport Psychologist, 15, 276-287.

Elfving, T., Riches, D., Lintunen, T., Watt, T., \& Morris, T. (2001). Reliability, factor structure and criterion validity of the Sport Imagery Ability Measure (SIAM) in athletes from Finland. In A. Papaioannou, M. Goudas, \& Y. Theodorakis (eds.), Proceeding of the $X^{\text {th }}$ World Congress of Sport Psychology (pp. 49-51). Athens, Greece: ISSP.

Ferguson, G., \& Takane, Y. (2009). Analiza statystyczna w psychologii i pedagogice [Statisctic analysis in psychology and pedagogy]. Warszawa: Wydawnictwo Naukowe PWN.

Fery, Y. A., \& Morizot, P. (2000). Kinesthetic and visual image in modeling closed motor skills: The example of the tennis serve. Perceptual \& Motor Skills, 90, 707-722.

Fourkas, A. D., Avenanti, A., Urgesi, C., \& Aglioti, S. M. (2006). Corticospinal facilitation during first and third person imagery. Experimental Brain Research, 168, 143-151.

Goss, S., Hall, C., \& Buckolz, E. (1983). Visual and kinesthetic imagery of movements in elementary school children. Canadian Journal of Applied Sport Sciences, 8, 209.

Greenwald, A. G. (1970). Sensory feedback mechanisms in performance control: With special reference to the ideomotor mechanism. Psychological Review, 77, 73-99.

Gregg, M., \& Hall, C. (2006). Measurement of motivational imagery abilities in sport. Journal of Sports Sciences, 24, 961-971.

Gregg, M., Hall, C., \& Butler, A. (2010). The MIQ-RS: A suitable option for examining movement imagery ability. Evidence-Based Complementary and Alternative Medicine, 7, 249-257.

Hall, C. R. (2001). Imagery in sport and exercise. In R. N. Singer, H. A. Hausenblas, \& C. M. Janelle (eds.), Handbook of research on sport psychology ( $2^{\text {nd }}$ ed.) (pp. 529-549). New York: John Wiley $\&$ Sons Inc.

Hall, C. R., \& Martin, K. A. (1997). Measuring movement imagery abilities: A revision of the movement imagery questionnaire. Journal of Mental Imagery, 21, 143-154.

Hall, C. R., Pongrac, C., \& Buckholz, E. (1985). The measurement of imagery ability. Human Movement Science, 4, 107-118.

Hardy, L., \& Callow, N. (1999). Efficacy of external and internal visual imagery perspectives for the enhancement of performance on tasks in which form is important. Journal of Sport and Exercise Psychology, 21, 95-112.

Howell, D. C. (2013). Statistical Methods for Psychology. $8^{\text {th }}$ ed. University of Vermont.

Isaac, A. R., Marks, D. F., \& Russell, D. G. (1986). An instrument for assessing imagery of movement:
The vividness of Movement Imagery Questionnaire (VMIQ). Journal of Mental Imagery, 10, 23-30.

Kenny, D. A. (2004). Terminology and basics of SEM. Retrieved April 1, 2009, from http:// davidakenny. net $/ \mathrm{cm} /$ basics.htm.

Konarski, R. (2010). Modele Równań Strukturalnych [Structural Equation Models]. Warszawa: Wydawnictwo Naukowe PWN.

Lorant, J., \& Nicholas, A. (2004). Validation de la traduction française du Movement Imagery Questionnaire-Revised (MIQ-R) [Validation of the French translation of the Movement Imagery Questionnaire-Revised (MIQ-R)]. Science \& Motricite, 53, 57-68.

Martens, R. (1982). Imagery in sport. Paper presented at the conference on Medical and Scientific Aspects of Elitism in Sport. Brisbane, Australia.

Mendes, P., Marinho, D., \& Petrica, J. (2015). Comparison between genders in imagery ability in Portuguese basketball practitioners. Journal of Physical Education and Sport, 15, 391.

Monsma, E. V., Short, S. E., Hall, C. R., Gregg, M., \& Sullivan, P. (2009). Psychometric properties of the revised Movement Imagery Questionnaire (MIQ-R). Journal of Imagery Research in Sport and Physical Activity, 4, 1-12.

Morris, T., Spittle, M., \& Watt, A. (2005). Imagery in Sport. Champaign, IL: Human Kinetics.

Nezam, S., IsaZadeh, H., Hojati, A., \& Zadeh, Z. (2014). Comparison Ability of Movement Imagery perspectives in Elite, Sub-Elite and non Elite Athletes. International Research Journal of Applied and Basic Sciences, 8, 712-716.

Ozel, S., Molinaro, C., \& Larue, J. (2001). Influence of sport on gender differences in spatial imagery. Homeostasis in Health and Disease, 41, 169-175.

Perry, C., \& Morris, T. (1995). Mental imagery in sport. In T. Morris \& J. Summers (eds.), Sport psychology: Theories, applications and issues (pp. 339385). Brisbane, Australia: Wiley.

Richardson, A. (1994). Individual differences in imaging: Their measurement, origins, and consequences. Amityville, NY: Baywood.

Richardson, J. T. E. (1995). Gender differences in the Vividness of Visual Imagery Questionnaire: A metaanalysis. Journal of Mental Imagery, 19, 177-187.

Richardson, J. T. E. (1999). Imagery. Hove: Psychology Press.

Roberts, R., Callow, N., Hardy, L., Markland, D., \& Bringer, J. (2008). Movement imagery ability: Development and assessment of a revised version of the vividness of movement imagery questionnaire. Journal of Sport \& Exercise Psychology, 30, 200-221.

Rodgers, W., Hall, C., \& Buckolz, E. (1991). The effect of an imagery training program on imagery ability, imagery use, and figure skating performance. Journal of Applied Sport Psychology, 3, 109-125. 
Ruby, P., \& Decety, J. (2001). Effect of subjective perspective taking during simulation of action: a PET investigation of agency. Nature Neuroscience, 4, 546-550.

Ruiz, M. C., \& Watt, A. P. (2014). Psychometric characteristics of the Spanish version of the Sport Imagery Questionnaire. Psicothema, 26, 267-272.

Schmidt, R. A., \& Wrisberg, C. A. (2004). Motor learning and performance ( $3^{\text {rd }}$ ed.). Champaign, IL: $\mathrm{Hu}-$ man Kinetics Publishing House.

Sheehan, P. W., Ashton, R., \& White, K. (1983). Assessment of mental imagery. In A. A. Sheikh (ed.), Imagery: Current theory, research, and application (pp. 189-221). New York: Wiley.

Smyth, M. M., \& Waller, A. (1998). Movement imagery in rock climbing: Patterns of interference from visual, spatial and kinaesthetic secondary tasks. Applied Cognitive Psychology, 12, 145-157.

Taktek, K. (2004). The effects of mental imagery on the acquisition of motor skills and performance: A literature review. Journal of Mental Imagery, 28, 79-114.

Vadocz, E., Hall, C. R., \& Moritz, S. E. (1997). The relationship between competitive anxiety and imagery use. Journal of Applied Sport Psychology, 9, 241-253.

Vealey, R., \& Greenleaf C. A. (1998). Seeing is believing: Understanding and Using imagery in sport. In J. M. Williams (ed.), Applied sport psychology: Personal growth to peak performance ( $3^{\text {rd }} \mathrm{ed}$.) (pp. 247-283). Mountain View, CA: Mayfield.

Vealey, R. S. (1986). Imagery training for performance enhancement. In J. M. Williams (ed.), Applied sport psychology: Personal growth to peak performance ( $1^{\text {st }}$ ed.) (pp. 209-231). Mountain View, CA: Mayfield.

Vealey, R. S., \& Walter, S. M. (1993). Imagery training for performance enhancement and personal development. In J. M. Williams (ed.), Applied sport psychology: Personal growth to peak performance ( $2^{\text {nd }}$ ed.) (pp. 200-224). Mountain View, CA: Mayfield.

Watt, A. P., Morris, T., \& Andersen, M. B. (2004). Issues in the development of a measure of imagery ability in sport. Journal of Mental Imagery, 28, 149-180.

White, A., \& Hardy, L. (1995). Use of different imagery perspectives on the learning and performance of different motor skills. The British Journal of Psychology, 86, 169-180.

Williams, S. E., \& Cumming, J. (2011). Measuring Athlete Imagery Ability: The Sport Imagery Ability Questionnaire. Journal of Sport \& Exercise Psychology, 33, 416-440.

Williams, S., Cumming, J., Ntoumanis, N., Nordin-Bates, S. M., Ramsey, R., \& Hall, C. (2012). Further validation and development of the Movement Imagery Questionnaire. Journal of Sport \& Exercise Psychology, 34, 621-646. 
APpendix

Kwestionariusz obrazowania ruchu 3 (MIQ-3)

Adaptacja polska D. Budnik-Przybylska, M. Szczypińska, K. Karasiewicz

\section{OVERVIEW}

The MIQ-3 is the most recent version of the Movement Imagery Questionnaire (Hall \& Pongrac, 1983) and the Movement Imagery Questionnaire-Revised (Hall \& Martin, 1997). It is a 12-item questionnaire to assess an individual's ability to image four movements using internal visual imagery, external visual imagery, and kinesthetic imagery. The MIQ-3 has good psychometric properties, internal reliability, and predictive validity.

\section{Reference}

Williams, S. E., Cumming, J., Ntoumanis, N., Nordin-Bates, S. M., Ramsey, R., \& Hall, C. (2012). Further validation and development of the Movement Imagery Questionnaire. Journal of Sport \& Exercise Psychology, 34, 621-646.

To download the full paper: http://works.bepress.com/jennifer_cumming/27/

*If you decide to use the MIQ-3 in your research, please send any citations to j.cumming@bham.ac.uk and dagmara.budnik@ug.edu.pl.We will add this information to www.jennifercumming.com so that other interested imagery researchers can find your work. We would also appreciate receiving a copy of your research findings.

\section{PODSUMOWANIE}

Kwestionariusz MIQ-3 stanowi najnowszą wersję Kwestionariusza obrazowania ruchu MIQ (Hall \& Pongrac, 1983) oraz Zrewidowanego kwestionariusza obrazowania ruchu MIQ-R (Hall \& Martin, 1997). Składa się on z 12 punktów, które pozwalają ocenić umiejętność obrazowania czterech ruchów ciała za pomocą obrazowania wizualnego z perspektywy wewnętrznej, obrazowania wizualnego z perspektywy zewnętrznej oraz obrazowania kinestetycznego. Kwestionariusz MIQ-3 cechuje się dobrymi właściwościami psychometrycznymi, wewnętrzną spójnością oraz trafnością.

\section{PRZYPIS}

Williams, S. E., Cumming, J., Ntoumanis, N., Nordin-Bates, S. M., Ramsey, R., \& Hall, C. (2012). Further validation and development of the Movement Imagery Questionnaire [Dalsza walidacja i rozbudowa Kwestionariusza obrazowania ruchu]. Journal of Sport \& Exercise Psychology, 34, 621-646.

Cały dokument do pobrania pod linkiem http://works.bepress.com/jennifer_cumming/27/

*W przypadku korzystania z Kwestionariusza obrazowania ruchu 3 (MIQ-3) we własnych badaniach prosimy o przesłanie fragmentów pracy na adresy dagmara.budnik@ug.edu.pl i j.cumming@bham.ac.uk. Zostaną one dodane na stronie www.jennifercumming.com, aby ułatwić dostęp do nich innym badaczom obszaru obrazowania. Będziemy także wdzięczni za otrzymanie kopii wyników uzyskanych w takim badaniu. 
Kwestionariusz obrazowania ruchu 3 (MIQ-3)

Adaptacja polska D. Budnik-Przybylska, M. Szczypińska, K. Karasiewicz

Pełny kwestionariusz wraz z instrukcją

\section{Instrukcja}

Niniejszy kwestionariusz dotyczy dwóch sposobów, które są wykorzystywane przez niektórych ludzi do wewnętrznego („mentalnego”) wykonywania ruchów ciałem. Dotyczy to szczególnie niektórych rodzajów ruchu. Pierwszym ze sposobów jest próba stworzenia wizualnego obrazu ruchu w głowie. Drugim jest próba wewnętrznego odczucia ruchu bez faktycznego jego wykonywania. Proszę spróbować obu sposobów na wewnętrzne obrazowanie różnych ruchów, a następnie ocenić poziom trudności/łatwości w każdym przypadku. W takiej ocenie nie chodzi o to, czy wewnętrzna próba wykonania ruchu była lepsza lub gorsza. Chodzi o samą umiejętność wykonywania takiego rodzaju czynności w zakresie poszczególnych ruchów. Żadna odpowiedź nie jest ani dobra, ani zła, ani też lepsza lub gorsza od innej.

Każde z poniższych zdań opisuje jeden charakterystyczny ruch lub czynność. Proszę dokładnie przeczytać każde zdanie, a następnie faktycznie wykonać dany ruch tak, jak to opisano. Ruch należy wykonać tylko raz. Potem należy wrócić do początkowej pozycji ciała, tak jakby ruch miał zostać powtórzony. Następnie, w zależności od rodzaju żądanego obrazowania, należy: (1) utworzyć jak najbardziej konkretny i wyrazisty obraz wizualny tego ruchu, który został przed chwilą wykonany - z perspektywy wewnętrznej (tzn. z perspektywy pierwszoosobowej tak, jakbyś sam(a) wykonywał(a) ten ruch w rzeczywistości i obserwował(a) tę czynność własnymi oczami) LUB (2) utworzyć jak najbardziej konkretny i wyrazisty obraz wizualny tego ruchu, który został przed chwilą wykonany - z perspektywy zewnętrznej (tzn. z perspektywy osoby trzeciej tak, jakbyś obserwował(a) siebie na filmie), LUB (3) wewnętrznie poczuć odtwarzanie tego ruchu, który został przed chwilą wykonany.

Po wewnętrznym („mentalnym”) wykonaniu danego zadania należy ocenić, jak łatwa/trudna była jego realizacja. W tym celu stosowana jest poniższa skala oceny. Proszę dokonać oceny w jak najbardziej precyzyjny sposób, spędzając nad tym tyle czasu, ile będzie niezbędne dla rzetelnego ocenienia każdego ruchu. Oceny mogą się powtarzać dla różnych ruchów, które zostały wewnętrznie „zobaczone” lub „poczute" - nie trzeba wykorzystywać całej skali ocen.

\section{SKALA OCENY}

Skala dla obrazowania wizualnego

\begin{tabular}{ccccccc}
\hline 1 & 2 & 3 & 4 & 5 & 6 & 7 \\
\hline $\begin{array}{c}\text { Bardzo trudno } \\
\text { zobaczyć }\end{array}$ & $\begin{array}{c}\text { Trudno } \\
\text { zobaczyć }\end{array}$ & $\begin{array}{c}\text { Raczej trudno } \\
\text { zobaczyć }\end{array}$ & $\begin{array}{c}\text { Średnio } \\
\text { (ani łatwo, } \\
\text { ani trudno) }\end{array}$ & $\begin{array}{c}\text { Raczej łatwo } \\
\text { zobaczyć }\end{array}$ & $\begin{array}{c}\text { Łatwo } \\
\text { zobaczyć }\end{array}$ & $\begin{array}{c}\text { Bardzo łatwo } \\
\text { zobaczyć }\end{array}$ \\
\hline
\end{tabular}

Skala dla obrazowania kinestetycznego

\begin{tabular}{ccccccc}
\hline 1 & 2 & 3 & 4 & 5 & 6 & 7 \\
\hline $\begin{array}{c}\text { Bardzo trudno } \\
\text { poczuć }\end{array}$ & $\begin{array}{c}\text { Trudno } \\
\text { poczuć }\end{array}$ & $\begin{array}{c}\text { Raczej trudno } \\
\text { poczuć }\end{array}$ & $\begin{array}{c}\text { Średnio } \\
\text { (ani łatwo, } \\
\text { ani trudno) }\end{array}$ & $\begin{array}{c}\text { Raczej łatwo } \\
\text { poczuć }\end{array}$ & $\begin{array}{c}\text { Łatwo } \\
\text { poczuć }\end{array}$ & $\begin{array}{c}\text { Bardzo łatwo } \\
\text { poczuć }\end{array}$ \\
\hline
\end{tabular}


1. POZYCJA POCZACTKOWA: $\mathrm{RUCH}:$

WEWNĘTRZNIE:

Ocena:

2. POZYCJA POCZĄTKOWA: $\mathrm{RUCH}:$

WEWNĘTRZNIE:

Ocena:

3. POZYCJA POCZĄTKOWA:

$\mathrm{RUCH}:$

WEWNĘTRZNIE:

Ocena:

4. POZYCJA POCZĄTKOWA:

$\mathrm{RUCH}:$

WEWNĘTRZNIE:

Ocena:
Stań, trzymając stopy i nogi złączone, a ramiona wzdłuż ciała.

Podnieś prawe kolano najwyżej, jak się da - lewa noga pozostaje na ziemi, gdy prawa noga jest zgięta w kolanie. Następnie opuść prawą nogę i ponownie stań na obu. Wykonaj tę czynność powoli.

Przyjmij pozycję początkową. Spróbuj poczuć, jak wykonujesz ten ruch, który przed chwilą obserwowałeś(aś), lecz bez faktycznego wykonywania go. Następnie oceń, jak łatwe/trudne było takie wewnętrzne wykonanie tego zadania.

Stań, trzymając stopy i nogi złączone, a ramiona wzdłuż ciała.

Zrób niski skłon tułowia, a następnie podskocz najwyżej, jak ci się uda, wyprostowując oba ramiona ponad głowę. Wyląduj na ziemi, trzymając obie stopy osobno i opuszczając ramiona wzdłuż ciała.

Przyjmij pozycję początkową. Spróbuj zobaczyć, jak wykonujesz ten ruch, który przed chwilą obserwowałeś(aś) - z perspektywy wewnętrznej. Następnie oceń, jak łatwe/trudne było takie wewnętrzne wykonanie tego zadania.

Użyj ręki, która nie jest twoją dominującą ręką, i wyprostuj całe ramię w bok tak, aby było równolegle do ziemi - z dłonią zwróconą ku ziemi.

Przenieś ramię ku przodowi, aż będzie bezpośrednio z przodu ciała (cały czas równolegle do ziemi). Podczas wykonywania ruchu ramię powinno być wyprostowane. Wykonaj ruch powoli.

Przyjmij pozycję początkową. Spróbuj zobaczyć, jak wykonujesz ten ruch, który przed chwilą obserwowałeś(aś) - z perspektywy zewnętrznej. Następnie oceń, jak łatwe/trudne było takie wewnętrzne wykonanie tego zadania. Oceń także kąt, z którego ruch był obserwowany.

Stań, trzymając stopy nieznacznie rozłączone, a ramiona wyciągnięte nad głową.

Powoli nachyl tułów do przodu, zginając się w pasie, aż dłońmi dotkniesz palców u stóp (a jeśli potrafisz, to dotknij podłogi palcami lub całymi dłońmi). Powróć do pozycji początkowej i stań prosto z ramionami wyprostowanymi nad głową.

Przyjmij pozycję początkową. Spróbuj poczuć, jak wykonujesz ten ruch, który przed chwilą obserwowałeś(aś), lecz bez faktycznego wykonywania go. Następnie oceń, jak łatwe/trudne było takie wewnętrzne wykonanie tego zadania. 
5. POZYCJA POCZĄTKOWA: $\mathrm{RUCH}$ :

WEWNĘTRZNIE:

$$
\text { Ocena: }
$$

6. POZYCJA POCZĄTKOWA: $\mathrm{RUCH}$ :

WEWNĘTRZNIE:

Ocena:

7. POZYCJA POCZĄTKOWA:

RUCH:

WEWNĘTRZNIE:

Ocena:

8. POZYCJA POCZĄTKOWA:

RUCH:

WEWNĘTRZNIE:

Ocena:
Stań, trzymając stopy i nogi złączone, a ramiona wzdłuż ciała.

Podnieś prawe kolano najwyżej, jak się da - lewa noga pozostaje na ziemi, gdy prawa noga jest zgięta w kolanie. Następnie opuść prawą nogę i ponownie stań na obu. Wykonaj tę czynność powoli.

Przyjmij pozycję początkową. Spróbuj zobaczyć, jak wykonujesz ten ruch, który przed chwilą obserwowałeś(aś) - z perspektywy wewnętrznej. Następnie oceń, jak łatwe/trudne było takie wewnętrzne wykonanie tego zadania.

Stań, trzymając stopy i nogi złączone, a ramiona wzdłuż ciała.

Zrób niski skłon tułowia, a następnie podskocz najwyżej, jak ci się uda, wyprostowując oba ramiona ponad głowę. Wyląduj na ziemi, trzymając obie stopy osobno i opuszczając ramiona wzdłuż ciała.

Przyjmij pozycję początkową. Spróbuj zobaczyć, jak wykonujesz ten ruch, który przed chwilą obserwowałeś(aś) - z perspektywy zewnętrznej. Następnie oceń, jak łatwe/trudne było takie wewnętrzne wykonanie tego zadania. Oceń także kąt, z którego ruch był obserwowany.

Użyj ręki, która nie jest twoją dominującą ręką, i wyprostuj całe ramię w bok tak, aby było równolegle do ziemi - z dłonią zwróconą ku ziemi.

Przenieś ramię ku przodowi, aż będzie bezpośrednio z przodu ciała (cały czas równolegle do ziemi). Podczas wykonywania ruchu ramię powinno być wyprostowane. Wykonaj ruch powoli.

Przyjmij pozycję początkową. Spróbuj poczuć, jak wykonujesz ten ruch, który przed chwilą wykonywałeś(aś), lecz bez faktycznego wykonywania go. Następnie oceń, jak łatwe/trudne było takie wewnętrzne wykonanie tego zadania.

Stań, trzymając stopy nieznacznie rozłączone, a ramiona wyciągnięte nad głową.

Powoli nachyl tułów do przodu, zginając się w pasie, aż dłońmi dotkniesz palców u stóp (a jeśli potrafisz, to dotknij podłogi palcami lub całymi dłońmi). Powróć do pozycji początkowej i stań prosto z ramionami wyprostowanymi nad głową.

Przyjmij pozycję początkową. Spróbuj zobaczyć, jak wykonujesz ten ruch, który przed chwilą obserwowałeś(aś) - z perspektywy wewnętrznej. Następnie oceń, jak łatwe/trudne było takie wewnętrzne wykonanie tego zadania. 
9. POZYCJA POCZĄTKOWA: $\mathrm{RUCH}:$

WEWNĘTRZNIE:

Ocena:

10.

POZYCJA POCZĄTKOWA: $\mathrm{RUCH}:$

WEWNĘTRZNIE:

\author{
Ocena:
}

11. POZYCJA POCZĄTKOWA:

$\mathrm{RUCH}:$

WEWNĘTRZNIE:

Ocena:

12. POZYCJA POCZĄTKOWA:

$\mathrm{RUCH}$ :

WEWNĘTRZNIE:

Ocena:
Stań, trzymając stopy i nogi złączone, a ramiona wzdłuż ciała.

Podnieś prawe kolano najwyżej, jak się da - lewa noga pozostaje na ziemi, gdy prawa noga jest zgięta w kolanie. Następnie, opuść prawą nogę i ponownie stań na obu. Wykonaj tę czynność powoli.

Przyjmij pozycję początkową. Spróbuj zobaczyć, jak wykonujesz ten ruch, który przed chwilą obserwowałeś(aś) - z perspektywy zewnętrznej. Następnie oceń, jak łatwe/trudne było takie wewnętrzne wykonanie tego zadania. Oceń także kąt, z którego ruch był obserwowany.

Stań, trzymając stopy i nogi złączone, a ramiona wzdłuż ciała.

Zrób niski skłon tułowia, a następnie podskocz najwyżej, jak ci się uda, wyprostowując oba ramiona ponad głowę. Wyląduj na ziemi, trzymając obie stopy osobno i opuszczając ramiona wzdłuż ciała.

Przyjmij pozycję początkową. Spróbuj poczuć, jak wykonujesz ten ruch, który przed chwilą wykonywałeś(aś), lecz bez faktycznego wykonywania go. Następnie oceń, jak łatwe/trudne było takie wewnętrzne wykonanie tego zadania.

Użyj ręki, która nie jest twoją dominującą ręką, i wyprostuj całe ramię w bok tak, aby było równolegle do ziemi - z dłonią zwróconą ku ziemi.

Przenieś ramię ku przodowi, aż będzie bezpośrednio z przodu ciała (cały czas równolegle do ziemi). Podczas wykonywania ruchu ramię powinno być wyprostowane. Wykonaj ruch powoli.

Przyjmij pozycję początkową. Spróbuj zobaczyć, jak wykonujesz ten ruch, który przed chwilą obserwowałeś(aś) - z perspektywy wewnętrznej. Następnie oceń, jak łatwe/trudne było takie wewnętrzne wykonanie tego zadania.

Stań, trzymając stopy nieznacznie rozłączone, a ramiona wyciągnięte nad głową.

Powoli nachyl tułów do przodu, zginając się w pasie, aż dłońmi dotkniesz palców u stóp (a jeśli potrafisz, to dotknij podłogi palcami lub całymi dłońmi). Powróć do pozycji początkowej i stań prosto z ramionami wyprostowanymi nad głową.

Przyjmij pozycję początkową. Spróbuj zobaczyć, jak wykonujesz ten ruch, który przed chwilą obserwowałeś(aś) - z perspektywy zewnętrznej. Następnie oceń, jak łatwe/trudne było takie wewnętrzne wykonanie tego zadania. Oceń także kąt, z którego ruch był obserwowany. 
Kwestionariusz obrazowania ruchu 3 (MIQ-3)

Adaptacja polska D. Budnik-Przybylska, M. Szczypińska, K. Karasiewicz

\section{Formularz odpowiedzi}

(w przypadku odczytywania Instrukcji i zadań)

Po wewnętrznym (,mentalnym”) wykonaniu danego zadania należy ocenić, jak łatwa/trudna była jego realizacja, używając do tego poniższego pola. W tym celu stosowana jest poniższa skala oceny. Proszę dokonać oceny w jak najbardziej precyzyjny sposób, spędzając nad tym tyle czasu, ile będzie niezbędne dla rzetelnego ocenienia każdego ruchu. Oceny mogą się powtarzać dla różnych ruchów, które zostały wewnętrznie „zobaczone” lub „poczute” - nie trzeba wykorzystywać całej skali ocen.

\section{SKALA OCENY}

Skala dla obrazowania wizualnego

\begin{tabular}{ccccccc}
\hline 1 & 2 & 3 & 4 & 5 & 6 & 7 \\
\hline $\begin{array}{c}\text { Bardzo trudno } \\
\text { zobaczyć }\end{array}$ & $\begin{array}{c}\text { Trudno } \\
\text { zobaczyć }\end{array}$ & $\begin{array}{c}\text { Raczej trudno } \\
\text { zobaczyć }\end{array}$ & $\begin{array}{c}\text { Średnio } \\
\text { (ani łatwo, } \\
\text { ani trudno) }\end{array}$ & $\begin{array}{c}\text { Raczej łatwo } \\
\text { zobaczyć }\end{array}$ & $\begin{array}{c}\text { Łatwo } \\
\text { zobaczyć }\end{array}$ & $\begin{array}{c}\text { Bardzo łatwo } \\
\text { zobaczyć }\end{array}$ \\
\hline
\end{tabular}

Skala dla obrazowania kinestetycznego

\begin{tabular}{|c|c|c|c|c|c|c|}
\hline 1 & 2 & 3 & 4 & 5 & 6 & 7 \\
\hline $\begin{array}{l}\text { Bardzo trudno } \\
\text { poczuć }\end{array}$ & $\begin{array}{l}\text { Trudno } \\
\text { poczuć }\end{array}$ & $\begin{array}{l}\text { Raczej trudno } \\
\text { poczuć }\end{array}$ & $\begin{array}{c}\text { Średnio } \\
\text { (ani łatwo, } \\
\text { ani trudno) }\end{array}$ & $\begin{array}{c}\text { Raczej łatwo } \\
\text { poczuć }\end{array}$ & $\begin{array}{l}\text { Łatwo } \\
\text { poczuć }\end{array}$ & $\begin{array}{c}\text { Bardzo łatwo } \\
\text { poczuć }\end{array}$ \\
\hline
\end{tabular}

\begin{tabular}{llll}
\hline 1) Podniesienie kolana & Ocena: ___ & 7) Ruch ramieniem & Ocena: ___ \\
\hline 2) Podskok & Ocena: ____ & 8) Skłon w pasie & Ocena: ___ \\
\hline 3) Ruch ramieniem & Ocena: ____ & 9) Podniesienie kolana & Ocena: ____ \\
\hline 4) Skłon w pasie & Ocena: ____ & 10) Podskok & Ocena: ___ \\
\hline 5) Podniesienie kolana & Ocena: ___ & 11) Ruch ramieniem & Ocena: ___ \\
\hline 6) Podskok & Ocena: & 12) Skłon w pasie & Ocena: ____
\end{tabular}

